\title{
ENFORCEABILITY OF INTERNATIONAL HUMANITARIAN LAW IN ARMED CONFLICT AT PRESENT
}

Lina Hastuti, Lecturer, Airlangga University, Surabaya, Indonesia. E-mail: lina.hastuti@gmail.com

Abstract: The tendency of the current conflict is a new type of conflict, which is not regulated by international humanitarian law. After World War II, in any war, emphasize the protection of victims of war and an obligation to be responsible for violations of international law or international humanitarian law. The purpose this research is to explore the theories or the law resources in International Humanitarian Law to facing a new type of armed conflict. It is also significant to know where the discovered principles international humanitarian law about the problem. Based on Martens Clause and 1977 Additional Protocol I and II or Si Omnes Clause and Common Articles 2 Geneva Conventions 1949 can applied in new type of armed conflicts. As the development of international humanitarian law which always follow the development of the international community, to address issues related to a new type of armed conflict, it can be back to the theories and legal resources in international humanitarian law.

Keywords: Armed Conflict, International Humanitarian Law.

\section{INTRODUCTION}

Some of the armed conflict at present that emerged in the last decade often reveal a new type of a conflict, which may not be known in advance because one of the parties involved can not be classified as a state or a rebel. It can be seen, for example, the conflict between Hezbollah and Israel Group in 2006 or conflict between groups of Islamic State of Iraq and Syria (ISIS) in Iraq and Syria, or even the latest conflict in Yemen. In the Israeli-Hezbollah conflict, Hezbollah is armed resistance groups in Lebanon, but is formed by other countries (Iran and Syria) and in the conflict against Israel. 
While in Iraq and Syria, ISIS is an extremist group that declared the establishment of an Islamic country that stretches across the territory they control in Iraq and Syria into one of the caliphate.

Such a situation creates problems associated with this type of conflict, including which types, an international armed conflict or non-international armed conflict or other types of conflict? In such situations, the law is applicable and can be applied? Questions like these arise common and interesting to be analyzed. Is international humanitarian law can be applied? In the conventional view, the socalled conflict or war according to international humanitarian law covering international armed conflict and non-international armed conflict. Referred to as an international armed conflict is a conflict between states, while the non-international armed conflicts occurred in the territory of a country where there is a conflict between the government and rebels.

In the above-mentioned conflict if grouped in an international armed conflict is not appropriate because one of the parties is not a state, while if it is referred to as a non-international armed conflict is not fitting for a sort of armed group Hezbollah and ISIS are not against the legitimate government or other insurgent groups in a country but against other countries. Likewise, other conflicts, passing an internal conflict in a country, but when examined it turns out there is involvement of other countries.

This paper attempts to examine the deeper theories and provisions of international humanitarian law and likely to be applicable to the types of conflicts so, given the possibility in the future will be more emerging types of conflicts that are not known beforehand.

\section{TYPES OF ARMED CONFLICT ACCORDING TO INTERNATIONAL HUMANITARIAN LAW}

In principle asserts Humanitarian Law, the countries involved in armed conflict situations should give protection to the victims and restricts the means and methods of war. The protection of 
victims became a major destination for international humanitarian law in regulating and apply the provisions. For it is held on the grounds of classification of armed conflict to protect the civilian population against the effects of hostilities; protect people from the adverse group; and related to the mechanisms of monitoring and enforcement. In this regard, international humanitarian law of armed conflict divides into two, namely international armed conflicts and conflicts of non-international armed.

International armed conflict is a conflict between the state ${ }^{1}$ and regulated in almost all the provisions of international humanitarian law. During its development, with the 1977 Protocol I definition contained in the Geneva Conventions of 1949 plus, which are included in this case is a situation which is equated with an international armed conflict, which had not previously contained in the Geneva Conventions of 1949. The situation is commonly called the CAR conflict, namely colonial domination, alien occupation and racist regime.

Non-international armed conflict is a conflict in the territory of a country, involving government forces and armed groups. In International Humanitarian Law, this type of conflict began to set in through common articles of Article 3 of the Geneva Conventions and the 1949 Additional Protocol II of 1977. Since the end of World War II, most of the conflicts are non-international armed conflict.

Difference between the two relevant is the issue of prisoners of war status. In situations of international armed conflict, when the person involved in the war or combatants captured by the enemy, then it should be treated as prisoners of war, not as a criminal. Prisoner of war status is in non-international armed conflict is not known, although it is possible if the parties to the dispute made a special

Definitions Article 2 of the 1949 Geneva Convention Commentary 1949, an international armed conflict expressed arising any difference difference between two states and leading intervention leading to the intervention of members of the armed force is an armed conflict within of the meaning of the article 2, even if one of the parties denies the existance of a state of war. It is a make no difference how long the conflict lasts, or how much slaughter takes places. 
deal on this. ${ }^{2}$ Another difference lies in the nature and the number of countries that are parties and the legal status of the parties involved in the conflict. In international armed conflict, it was two or more countries, while non-international conflicts wars involving the armed forces of a country against non-state armed groups (occurring in an area of the country). While the legal status of the parties, if the international armed conflict, the parties involved in both the state ${ }^{3}$ or an entity that is equivalent to the state, ${ }^{4}$ then the non-international conflict, which one is a state party, the other non-state armed groups.

\section{THE OTHER TYPE OF CONFLICT}

Actually, in addition to the two types of conflict as above, also known as conflict or tension in the country or internal disturbances and tension, that tension or unrest in the country. The characteristics of this type of conflict is the large scale arrests; large number of political prisoners; the probable existence of ill-treatment or inhumane condition of detention; the suspension of fundamental judicial guaranties, either as part of the promulgation of a state of emergency or simply as a matter of fact and allegation of disappearances. Comments on Additional Protocol I of 1977, internal disturbances and tension is unrest sporadic and isolated conducted military operations conducted against armed forces against similar actions, in certain cases is to arrest a large number of people over their activities.

2 As the provisions of Article 1 (4) Protocol I, every folk rebels captured by the ruler can be treated as prisoners of war, on condition that the ruler of the governments of other countries that were colonized or occupation or the government that runs the racial regime. This provision is completed by Article 96 paragraph (3) of Protocol I, which is the rebel authorities shall communicate his wishes to the depository country (state storage) to the Geneva Conventions. It was in anticipation of the fact that according to the national law of each country generally, state or government has the right crack down and punish the rebels in the country. Also there are opportunities such as the above application of Protocol I is not automatic, especially considering that it is usually not a country rebel groups so that no party can enjoy the rights of a State Party to the Geneva Conventions and their Additional Protocol

Article 2 Geneva Convention 1949

Article 1 (4) juncto Article 96 (3) Additional Protocol of 1977. 
In this situation that applies is the national law of the country concerned. That is more, humanitarian law can not be enforced. Thus, the obvious fact that in conflict situations, the law otherwise applicable international humanitarian law will apply domestic law. The development of human civilization for the advancement of science and technology as well as the increasingly diverse interests of the various parties led to conflicts that arise can not always be simply classified into one of the types of conflicts that are known beforehand.

The fact that armed conflicts are always side by side with human life has actually been around since human life there. After an attempt to nullify the things that are not possible, then you can do is set it up. Almost all of the provisions of the law of war emphasis on interstate war setting. Traditional martial law as contained in the 1907 Hague Convention and the Geneva Convention of 1929, does not contain provisions relating to civil war or insurrection. Likewise, international humanitarian law as we know it today, did not set aside what we know as an international armed conflict and a bit of a noninternational armed conflict.

In addition to the fact an increasing number of armed conflicts since 1945 , new forms of conflict is also growing, even since it's more noninternational conflicts, such as the national liberation war, guerrilla warfare, civil war and others. Technological development has also resulted in the development of weapons. In 1997, 25 armed conflicts occurred in 24 places in the world, namely in the African continent. Continent of Africa was the only region where the intensity of the conflict is very high and in every battle that occurred causing many deaths. ${ }^{5}$ Recent conflicts show the same thing which the country states to use military means to deal with radical groups, for example the situation in Syria / Iraq (ISIS), Nigeria (Boko Haram), Somalia and Yemen.

Conflict is the case in the past decade indicate that conflicts are not included in the conflict that has been prearranged. Not that such conflict is a new kind of conflict, once again the conflict that has

Dwight Jon Zimmerman, The Book of War, Tess Press Black Dog \& Leventhal Publishers, New York, 2008, p. 14. 
long existed but lately more and more complex from the point of view. Of the parties involved, the scene of the conflict, the number of victims, targeted to the harm caused.

Indiscriminately is characteristic of many conflicts and situations of armed violence. Combat between the army and armed groups accompanied by tension and violence between communities, for example in South Sudan and the Democratic Republic of Congo which has left thousands of people displaced, separated from their families or the more extreme, death. Conflicts protracted humanitarian consequences, especially the cost and man, the effects of which affect the life and human dignity, the state and its legitimacy. Atrocities in excess of humanity, both the parties involved and the civilian population. The breakdown of access to resources that are vital to human life such as water, energy, communications and other accesses. ${ }^{6}$

\section{ENFORCEABILITYOFINTERNATIONALHUMANITARIAN LAW}

The classification of the conflict into two types according to the International Humanitarian Law is not to limit the applicability of the rules regarding the war only to be applied in the two types of conflict. But is intended for the protection of the rights and obligations of the parties. Meanwhile, the International Humanitarian Law has the objective to reduce the suffering and prevent abuse or excessive of the parties. The underlying spirit is the fact that the war can not be eliminated, which can be done is to make regulations that would restrict the rights of the parties and to protect the victims of war based on humanity. Since ancient times to the present day always made efforts to make provisions that are tailored to the development of science technology and the international community.

In any conflict, the need for more fundamental in humanitarian efforts to reach out to all those affected and provide assistance as needed. This is evident in the changing focus settings International

Christoph Sutter, ICRC Reaching People in Need, Round Table 150 Years of Humanitarian Actions, Jakarta, 14 Oktober 2014. 
Humanitarian Law, which was originally set up methods and means of warfare, the provisions of the Geneva Conventions of 1949 through the fourth convention agreed more emphasis on the protection of war victims. Likewise, the further development, refinement is no longer held Hague Conventions of 1899 and 1907 but the 1949 Geneva Conventions by Additional Protocol I and II of 1977.

Related to non-international armed conflicts as well. The principle of humanity underlying the international community's efforts to regulate the armed conflict that actually occurred in the territory of a country and more a domestic affairs of that country, which at the end of International Law by the International Humanitarian Law managed to set it up in the common articles of Article 3 of the Geneva Conventions of 1949 and fitted through the Additional Protocol II. Special Additional Protocol II, Article 1, paragraph (1) confirmed that the Protocol applies to all armed conflicts which are not included in Additional Protocol I, which occurs in the territory of a State Party between its armed forces with a rebel armed forces or other organized armed groups, are:

a. under the commander in charge;

b. execute such control over a part of its territory which allows them;

c. to conduct joint military operations and sustainable and

d. to implement this Protocol.

Some things are not set explicitly in the Protocol, however, do not reduce the protection afforded to victims. For example, the Protocol does not contain rules concerning the status of prisoners of war, but in a defined protocol fundamental guarantees of humane treatment for people who are not involved in armed conflict or those who were detained and secured related to the armed conflict in question. Similarly, with regard to civil protection and its relation to the means and methods of warfare, the Protocol confirmed the prohibition on acts that caused the population suffer from hunger. ${ }^{7}$ Prohibited also move civilians forcibly or arbitrarily. ${ }^{8}$ 
Besides based on the provisions contained in various international treaties, when in a conflict situation is not found provisions set, in International Humanitarian Law, known as Martens Clause. The preamble of the 1899 Hague Convention II states until a more complete code of the laws of war is issued, the High Contracting Parties think it right to declare that in cases not included in the Regulations adopted by them, populations and belligerents remain under the protection and empire of the principles of international law, as they result from the usages established between civilized nations, from the laws of humanity and the requirements of the public conscience. The purpose of this clause is to anticipate the absence of provisions that can be applied in situations of conflict in order to avoid abuses committed by the commanders of the reason there are no provisions.

Marten clause is then underlying the provisions of subsequent agreements, as contained in Article 75 of Additional Protocol I of 1977 on the fundamental guarantees for people who are in the power of a party to the conflict. People who do not benefit from favorable treatment of the Convention or the Protocol shall be treated with humanity in all circumstances and shall enjoy, at least the specified protection regardless of race, color, sex, language, religion or belief, political opinion or other, national or social origin, property, birth or other position or above benchmarks other similar size.

Article 75 can not be removed with the provisions of Article 1 (2) The same protocol that contains recognition at once affirmation Martens Clause. Thus, if in conflict situations which are not governed by international humanitarian law, or the tensions and disturbances in the country as referred to in Article 1 (2) of this Protocol, particularly in cases where no rules, of course, the fixed under protection based on principles of humanity (the principles of humanity) and the dictates of the public conscience (conscience general). In addition to in Protocol I, Martens Clause is also contained in the Preamble to the Hague Convention IV of 1907; Opening of Conventional Weapons Convention in 1980; Article 63 of Geneva Convention I 1949; [62 / II; 142 / III; 158 / IV]. 


\section{CONCLUSION}

Humanitarian law through international treaty provisions set that can be applied in situations of international armed conflict and non-international. International humanitarian law also have been anticipated by several articles that expressly and clearly arranged for humanitarian protection and guarantee of fundamental treatment. If the conflict is not found provisions that govern them, the Martens Clause This became the basis of the applicability of international humanitarian law. Thus, based on the above, the current conflict situation, except the internal tension, humanitarian law can be applied.

\section{BIBLIOGRAPHY}

Sutter, C. (2014). ICRC Reaching People in Need, Round Table 150 Years of Humanitarian Actions, Jakarta.

Zimmerman, D. J. (2008). The book of war, New York: Tess Press Black Dog \& Leventhal Publishers, 